\title{
In vitro sensitivity of Corynespora cassiicola isolated from soybean to fungicides and field chemical control of target spot
}

\author{
Adriana Teramoto $^{1}$; Maurício Conrado Meyer ${ }^{2}$; Nelson Dias Suassuna ${ }^{3}$; Marcos Gomes da Cunha ${ }^{1}$
}

\author{
${ }^{1}$ Setor Fitossanitário, Escola de Agronomia, Universidade Federal de Goiás, Caixa Postal 131, 74001-970, Goiânia, Goiás, Brasil; ${ }^{2}$ Embrapa Soja, \\ Londrina, Paraná, Brasil; ${ }^{3}$ Embrapa Algodão, Santo Antônio de Goiás, Goiás, Brasil \\ Autor para correspondência: Adriana Teramoto (adritera@terra.com.br) \\ Data de chegada: 15/06/2016. Aceito para publicação em: 13/03/2017.
}

$10.1590 / 0100-5405 / 2195$

\section{ABSTRACT}

Teramoto, A.; Meyer, M.C.; Suassuna, N.D.; Cunha, M.G. In vitro sensitivity of Corynespora cassiicola isolated from soybean to fungicides and field chemical control of target spot. Summa Phytopathologica, v.43, n.4, p.281-289, 2017.

Soybean target spot (Corynespora cassiicola) has become an important disease in most soybean growing regions in Brazil. The sensitivity of 34 isolates of C. cassiicola to 11 fungicides was evaluated based on mycelial growth inhibition (boscalid, carbendazim, cyproconazole, fluopyram, fluxapyroxad, prothioconazole and thiophanate-methyl) or spore germination inhibition (azoxystrobin, picoxystrobin, pyraclostrobin and trifloxystrobin). In addition, the efficacy of five fungicides to control target spot was tested in four field trials carried out during three crop seasons: 2011/2012, 2012/2013 and 2013/2014. Fungal isolates were collected from soybean plants in several soybean growing areas in Brazil. The effective concentration of each fungicide to inhibit fungal growth or spore germination by $50 \%\left(\mathrm{EC}_{50}\right)$ was calculated for all isolates. Fluxapyroxad and prothioconazole provided the greatest mycelial growth inhibition and pyraclostrobin led to the lowest spore germination percentage, with the lowest $\mathrm{EC}_{50}$ values. At field experiments, cyproconazole and carbendazim showed target spot control ranging from $26 \%$ to $29 \%$. On the other hand, fluxapyroxad and prothioconazole prevented an epidemic of the disease by $45 \%$ to $55 \%$, respectively. In general, the efficacy of fungicides in the field reflected the in vitro sensitivity averages. Large sensitivity reduction was detected to benzimidazoles (MBC), indicating that this group of fungicides should no longer be used for target spot control. There was a negative and significant correlation $(-0.265)$ between target spot severity and soybean yield. The pathogen showed variability in sensitivity to the fungicide groups carboxamides (SDHI), triazoles (DMI) and strobilurins (QoI), which denotes a high risk of selection for resistance.

Keywords: fungicide sensitivity reduction; effective concentration; Glycine max; disease management.

\section{RESUMO}

Teramoto, A.; Meyer, M.C.; Suassuna, N.D.; Cunha, M.G. Sensibilidade de Corynespora cassiicola isolado de soja a fungicidas in vitro e controle químico de mancha-alvo da soja no campo. Summa Phytopathologica, v.43, n.4, p.281-289, 2017.

A mancha-alvo da soja (Corynespora cassiicola) tornou-se uma importante doença na maioria das regiões produtoras de soja no Brasil. A sensibilidade de 34 isolados de Corynespora cassiicola a 11 fungicidas foi avaliada pela inibição do crescimento micelial (boscalida, carbendazim, ciproconazol, fluopiram, fluxapiroxada, protioconazol e tiofanato-metílico) ou inibição da germinação de esporos (azoxistrobina, picoxistrobina, piraclostrobina e trifloxistrobina). Além disso, a eficácia de cinco fungicidas para controlar mancha-alvo foi testada em quatro ensaios no campo, conduzidos durante três safras: 2011/2012, 2012/2013 e 2013/2014. Os isolados do fungo foram coletados de plantas de soja em diversas regiões produtoras de soja do Brasil. A concentração efetiva para inibir o crescimento micelial ou a germinação dos esporos em 50\% $\left(\mathrm{EC}_{50}\right)$, para cada fungicida, foi calculada para todos os isolados. Fluxapiroxada e protioconazol proporcionaram as maiores inibições de crescimento micelial do patógeno e piraclostrobina a menor porcentagem de germinação de esporos, com os menores valores de $\mathrm{EC}_{50}$. Nos ensaios de campo, ciproconazol e carbendazim apresentaram percentuais de controle de mancha-alvo variando de $26 \%$ a $29 \%$. Por outro lado, fluxapiroxada e protioconazol preveniram a epidemia da doença na ordem de $45 \%$ e $55 \%$, respectivamente. No geral, a eficácia dos fungicidas no campo refletiu as médias de sensibilidade in vitro. Foi detectada ampla redução da sensibilidade aos benzimidazóis (MBC) indicando que esse grupo de fungicidas não deve ser mais usado no controle de mancha-alvo. Houve uma correlação negativa e significativa $(-0,265)$ entre severidade da doença e produção da soja. O patógeno mostrou variabilidade na sensibilidade aos grupos fungicidas carboxamidas (SDHI), triazóis (DMI) e estrobilurinas (QoI), o que demonstra alto risco de seleção para resistência.

Palavras-chave: redução da sensibilidade a fungicidas; concentração efetiva; Glycine max; manejo de doença.

Brazil is one of the world's major soybean producers [Glycine max (L.) Merr.], with 30.03 million hectares grown in 2014 season and a yield average of 2,882 $\mathrm{kg} \mathrm{ha}^{-1}(5)$. The country also has much arable land available for crop expansion, which has grown by $6.3 \%$ per year over the last five seasons (6). More than 50 diseases affect soybean crops in Brazil and they represent a major restrictive factor to increase productivity (30).

Target spot, caused by the fungus Corynespora cassiicola Berk. \& M. A. Curtis (Wei, 1950), was first detected in São Paulo State (2) and currently occurs in almost all soybean producing regions in Brazil (30). The pathogen infects both the upper part of the plant and the root system. Severe outbreaks occur both in regions of cool temperatures and in the warm highlands of the Brazilian savannah (30). Typical target spot symptoms are roughly circular necrotic leaf lesions ranging from little brown to $11 \mathrm{~mm}$-diameter spots, but they are typically large, circular, dark brown spots of approximately 4 to $5 \mathrm{~mm}$ in diameter, with a yellow margin. Large lesions occasionally exhibit a zonate pattern often associated with this disease, and the spots have a dark point in 
the center surrounded by darker concentric rings $(19,16)$.

The pathogen occurs in Brazilian soybean fields and affects a wide range of hosts, infecting a large number of native and cultivated plants (9). The fungus spreads mainly by means of infected seeds and survives in crop debris on the soil surface (1). Favorable environmental conditions for target spot outbreaks, i.e. temperatures above $25^{\circ} \mathrm{C}$ and relative humidity above $80 \%$ (16), can occur throughout the crop season in tropical and subtropical areas.

Although target spot is present in most soybean growing countries, economic damage is not frequently reported (28). In Brazil, target spot outbreaks have occurred in the main soybean growing areas and yield reduction of up to $21 \%$ has been reported (15). In the USA, incidence of target spot has increased in the southeast region, probably due to changes in weather patterns, pathogen virulence, and/or introduction of more susceptible host genotypes (19).

Measures for the management of target spot involve the use of partially resistant cultivars, seed treatment, crop rotation or succession with corn and other grass species, and chemical control by foliar fungicide spraying (29).

There are no resistant soybean cultivars to target spot (32). In the short term, the use of fungicides is required to control target spot in Brazilian soybean fields. Fungicide spraying to control foliar soybean diseases started with the emergence of Asian soybean rust caused by Phakopsora pachyrhizi Syd. \& P. Syd. (1914) in 2001, subsequently becoming one of the main strategies for the management of this disease and indispensable to maintain soybean economic production (30). In the 2011/2012 crop season, the cost of using foliar fungicides on soybeans amounted to US\$ 1.5 billion. Of this, $79 \%$ was spent on quinone outside inhibitors (QoI) and demethylation inhibitors (DMI), recommended for the control of Asian soybean rust, and 6\% was spent on methyl benzimidazole carbamates (MBC), recommended for the control of late season diseases, target spot and anthracnose $(18,30)$.

More recently, succinate dehydrogenase inhibitors (SDHI) fungicides have been used to control white mold [Sclerotinia sclerotiorum (Lib) de Bary], Asian soybean rust and target spot in Brazilian soybean fields (21).

Evidence of resistance of C. cassiicola to fungicides and reports of inconsistency of the efficiency of some fungicides to control soybean diseases $(4,31,32)$ seem to predict a threat to the stability of chemical control.

This study aimed to evaluate the in vitro sensitivity of $34 C$. cassiicola isolates from different Brazilian growing areas to 11 fungicides and to measure the efficacy of five fungicides in controlling target spot in field assays.

\section{MATERIALS AND METHODS}

\section{Fungicide treatments}

Technical grade fluxapyroxad (BAS $700 \mathrm{AC} \mathrm{F}$ ) was provided by BASF, while fluopyram (BCS 1015) and prothioconazole (Proline ${ }^{\circledR}$ ) were provided by Bayer CropScience. Commercial formulations of picoxystrobin (Oranis ${ }^{\circledR}$, DuPont), pyraclostrobin (Comet $^{\circledR}$, BASF), azoxystrobin (Priori ${ }^{\circledR}$, Syngenta), trifloxystrobin $\left(\right.$ Flint $^{\circledR}$, Bayer CropScience), carbendazim (Carbendazim NTX ${ }^{\circledR}$, Nortox), thiophanate-methyl (Cercobin ${ }^{\circledR}$, Iharabras), boscalid (Cantus ${ }^{\circledR}$, BASF) and cyproconazole (Alto $100^{\circledR}$, Syngenta) were purchased (Table 1).

Sampling, isolation and maintenance of $\boldsymbol{C}$. cassiicola isolates Isolates were collected from soybean growing areas in the states
Table 1. Commercial names, active ingredients (a.i.), names and concentrations, and mode of action (MOA) group of the fungicides used in this study.

\begin{tabular}{llcc}
\hline $\begin{array}{l}\text { Commercial } \\
\text { Name }\end{array}$ & $\begin{array}{l}\text { Active } \\
\text { Ingredient (a.i.) }\end{array}$ & $\begin{array}{c}\text { a.i. } \\
\text { Concentration }\end{array}$ & $\begin{array}{c}\text { MOA } \\
\text { Group }\end{array}$ \\
\hline Carbendazim NTX & Carbendazim & $50 \%$ & MBC \\
Cercobin & thiophanate-methyl & $50 \%$ & MBC \\
Alto 100 & Cyproconazole & $10 \%$ & DMI \\
Proline & Prothioconazole & $25 \%$ & DMI \\
Cantus & Boscalid & $50 \%$ & SDHI \\
Verango & Fluopyram & $50 \%$ & SDHI \\
BAS 700 & Fluxapyroxad & $30 \%$ & SDHI \\
Priori & Azoxystrobin & $25 \%$ & QoI \\
Oranis & Picoxystrobin & $25 \%$ & QoI \\
Comet & Pyraclostrobin & $25 \%$ & QoI \\
Flint & Trifloxystrobin & $50 \%$ & QoI \\
\hline
\end{tabular}

${ }^{1-}$ Mode of action fungicide group [(FRAC (12)]; MBC = Methyl Benzimidazole Carbamates; $\mathrm{DMI}=$ Demethylation Inhibitors; $\mathrm{SDHI}=$ Succinate Dehydrogenase Inhibitors and QoI = Quinone outside Inhibitors.

of Goiás, Mato Grosso, Mato Grosso do Sul, Maranhão, Minas Gerais, Tocantins, Paraná and Pará (Table 2). Isolates were identified based on morphological characters. Additionally, pathogenicity tests were carried out with two soybean cultivars to confirm Koch's postulates. From each sample, leaf fragments with pathogen structures were placed on a wateragar medium (WA) in Petri dishes ( $9 \mathrm{~cm}$ in diameter). After 3 to 5 days, mycelial disks $(5 \mathrm{~mm}$ ) from colony borders were cut from each colony and transferred to a potato dextrose agar medium (PDA). Petri dishes were maintained at $25^{\circ} \mathrm{C}$ and $12 \mathrm{~h}$-day length. Several $6 \mathrm{~mm}$-diameter mycelial disks were transferred to glass vials with sterilized distilled water (SDW) for long-term preservation, as described by Figueiredo (11). For each experiment, an isolate was subcultured through a maximum of five transfers. Six isolates were generously provided by Embrapa Soybean.

\section{In vitro mycelial growth inhibition of $C$. cassiicola}

Sensitivity of 34 isolates to carbendazim, thiophanate-methyl, fluxapyroxad, fluopyram, boscalid, prothioconazole and cyproconazole was estimated based on the colony growth inhibition. Fungicides were dissolved in SDW to obtain stock solutions of $1000 \mu \mathrm{g} \mathrm{mL}$ (for carbendazim and thiophanate-methyl) or $100 \mu \mathrm{g} \mathrm{mL}^{-1}$ (for the remaining fungicides). Based on preliminary tests, the stock solutions were added to a PDA medium after sterilization to produce final concentrations of $0,1.6,8,40,200$ and $1000 \mu$ g active ingredient (a.i.) of carbendazim or thiophanate-methyl $\mathrm{mL}^{-1}$, or $0,0.16,0.8,4,20$ and $100 \mu \mathrm{g}$ a.i. of fluxapyroxad, fluopyram, boscalid, prothioconazole and cyproconazole $\mathrm{mL}^{-1}$.

For each isolate, a $6 \mathrm{~mm}$-diameter mycelial plug was cut from the edge of a 10-day-old colony grown on PDA medium and placed in the center of a Petri dish with PDA added of each fungicide concentration. Each concentration (for each fungicide) was replicated five times. The plates were kept at $25^{\circ} \mathrm{C}$ in the dark. After 10 days, the colony diameter was measured in two perpendicular directions, and the diameter of the mycelial plug was subtracted before calculating the mean diameter of the colony (MD). For each concentration/fungicide, mycelial growth inhibition (MGI) of an isolate, $i$, was calculated by $\mathrm{MGI}=((\mathrm{MD} c$ - $\mathrm{MD} i) / \mathrm{MD} c$ ) x 100, where $\mathrm{MD} c=$ mean colony diameter for the control (no fungicide added), and $\mathrm{MD} i=$ mean colony diameter of the isolate grown on medium added of fungicide. For each replicate of 
Table 2. Origin of Corynespora cassiicola isolates and the number of isolates per Brazilian state.

\begin{tabular}{l|l}
\hline States & Population municipalities \\
\hline Goiás (GO) & $\begin{array}{l}\text { 6 isolates } \\
\text { (Morrinhos, Rio Verde, and Montividiu) }\end{array}$ \\
\hline Mato Grosso (MT) & $\begin{array}{l}11 \text { isolates } \\
\text { (Sinop, Sorriso, Querência, Nova } \\
\text { Mutum, Campo Novo Parecis, Itiquira, } \\
\text { Barra do Garças, and Nova Xavantina) }\end{array}$ \\
\hline Tocantins (TO) & $\begin{array}{l}3 \text { isolates } \\
\text { (Pedro Afonso) }\end{array}$ \\
\hline Paraná (PR) & $\begin{array}{l}3 \text { isolates } \\
\text { (Palotina, Nova Ventura de São Roque, } \\
\text { and Londrina) }\end{array}$ \\
\hline Maranhão (MA) & $\begin{array}{l}3 \text { isolates } \\
\text { (Tasso Fragoso) }\end{array}$ \\
\hline Minas Gerais (MG) & $\begin{array}{l}3 \text { isolates } \\
\text { (Tupaciguara) }\end{array}$ \\
\hline Mato Grosso do Sul (MS) & $\begin{array}{l}1 \text { isolate } \\
\text { (Maracaju) }\end{array}$ \\
\hline Pará (PA) & $\begin{array}{l}4 \text { isolates } \\
\text { (Dom Eliseu and Paragominas) }\end{array}$ \\
\hline Total & 34 isolates \\
\hline
\end{tabular}

each isolate-fungicide concentration combination, MGI $i$ values were linearly regressed on the logarithm $\left(\log _{10}\right)$ of fungicide concentration to estimate the dose that inhibited mycelial growth by $50 \%\left(\mathrm{EC}_{50}\right.$ value). For each fungicide group, the sensitivity of each isolate was established according to criteria defined by Edgington et al. (8) for MBC. For DMI and SDHI fungicides, as there were no previous references to $C$. cassiicola: $\mathrm{EC}_{50}$ values lower than the lowest tested concentration ( 0.16 $\left.\mu \mathrm{g} \mathrm{mL}^{-1}\right)$ were considered "Sensitive" $(\mathrm{S}) ; \mathrm{EC}_{50}$ values ranging from 0.16 to $1.0 \mu \mathrm{g} \mathrm{mL}^{-1}$ were considered "Moderately Sensitive" (MS); and $\mathrm{EC}_{50}$ values above $1.0 \mu \mathrm{g} \mathrm{mL}^{-1}$ were considered "Non-Sensitive" (NS). The sensitivity factor (SF) to fungicides was calculated as the highest $\mathrm{EC}_{50}$ value divided by the lowest $\mathrm{EC}_{50}$ value, in order to evaluate the extent of variability in fungicide sensitivity among the populations.

\section{In vitro inhibition of $\boldsymbol{C}$. cassiicola spore germination}

Previously, four Corynespora cassiicola isolates were tested for i) influence of salicylhydroxamic acid (SHAM) on spore germination and ii) evidence of the capability of C. cassiicola to overcome the toxicity of QoI fungicides through an alternative oxidative pathway. For the first test, water agar medium was used with $100 \mu \mathrm{g} . \mathrm{mL}^{-1}$ SHAM, as well as a control without SHAM. In addition, the influence of SHAM on in vitro spore germination was tested when added of QoI fungicides (azoxystrobin, picoxystrobin, pyraclostrobin, and trifloxystrobin) at $100 \mu \mathrm{g} \cdot \mathrm{mL}^{-1}$. The germination percentage values of the first assay were subjected to ANOVA to determine the effects of isolates and SHAM addition on the sensitivity of conidial germination. Chi-square tests were carried out for each combination (isolate $\mathrm{x}$ fungicide) to verify whether spore germination occurs at the same frequency with or without SHAM.

Sensitivity of the 34 isolates to the QoI fungicides picoxystrobin, pyraclostrobin, azoxystrobin and trifloxystrobin was estimated based on the spore germination inhibition. Fungicides were dissolved in SDW to obtain stock solutions of $100 \mu \mathrm{g}$ a.i. $\mathrm{mL}^{-1}$. Mycelium from 10-day-old colonies grown in Petri dishes containing PDA medium was gently agitated with $20 \mathrm{~mL}$ SDW to obtain a spore suspension. Suspensions were adjusted to a concentration of $10^{4}$ spores $\mathrm{mL}^{-1}$. Petri dishes $(5$ $\mathrm{cm}$ diameter) containing $5 \mathrm{~mL}$ of the water-agar medium (1.6\%) were added of stock solutions to produce the final concentrations $0,0.16$, $0.8,4,20$, and $100 \mu \mathrm{g} \mathrm{mL}^{-1}$. Then, $150 \mu \mathrm{l}$ of the spore suspension was deposited on the medium surface. The plates were kept in an incubator at $25^{\circ} \mathrm{C}$, in the dark, for $8 \mathrm{~h}$. Conidial germination (presence of a germ tube greater than the spore diameter) was determined visually by using a microscope at $100 \mathrm{X}$ magnification. In each replicate, 100 spores were counted per concentration. Results were expressed as the relative germinated spores (RGS) when compared with the control. For each concentration/fungicide, RGS of an isolate i was calculated by $\mathrm{RGS}=((\mathrm{GS} c-\mathrm{GS} i) / \mathrm{GS} c) \times 100$, where $\mathrm{GS} c=$ germinated spores for the control (no fungicide added), and GS $i=$ germinated spores of the isolate grown on medium added of fungicide. For each replicate of each isolate-fungicide concentration combination, RGSi values were linearly regressed on the logarithm $\left(\log _{10}\right)$ of fungicide concentration to estimate the dose that inhibited spore germination by $50 \%\left(\mathrm{EC}_{50}\right.$ value). The criteria used to establish the sensitivity level of the isolates to fungicides [as "Sensitive" (S), "Moderately Sensitive" (MS) or "NonSensitive" (NS) ] were based on those proposed by Leroux et al. (20) with modifications: sensitive $\left(\mathrm{EC}_{50}<0.16 \mu \mathrm{g} \mathrm{mL} \mathrm{m}^{-1}\right)$, weakly resistant $\left(\mathrm{EC}_{50}=0.16-1.0 \mu \mathrm{g} \mathrm{mL}^{-1}\right)$, and highly resistant $\left(\mathrm{EC}_{50}>1.0 \mu \mathrm{g} \mathrm{mL}^{-1}\right)$.

The sensitivity factor (SF) to fungicides was calculated as the highest $\mathrm{EC}_{50}$ value divided by the lowest $\mathrm{EC}_{50}$ value, in order to evaluate the extent of variability in fungicide sensitivity.

Effect of fungicides on target spot control under field conditions

Four field trials were conducted in Mato Grosso State to evaluate the efficacy of boscalid, carbendazim, cyproconazole, fluxapyroxad and prothioconazole in controlling soybean target spot. In the 2011/2012 crop season, one assay was conducted in Nova Xavantina Municipality with soybean cultivar TMG 132RR, which is susceptible to target spot. In 2012/2013, one assay was conducted in Nova Xavantina with the soybean cultivar TMG 1188RR. Planting was carried out on December 2, 2012. In 2013/2014, two assays were conducted in Nova Xavantina and Querência Municipalities with the soybean cultivars ST 820RR and BRSGO 8661RR, respectively. Sowing was carried out on December 5, 2013, in Nova Xavantina, and on November 30, 2013, in Querência. Rows were spaced 0.5 m apart, and plant density in each row was adjusted to 12 plants $\mathrm{m}^{-1}$. Experimental design was in randomized complete blocks with four replicates, and each plot was composed of four rows of $5 \mathrm{~m}$ each.

An isolate of C. cassiicola, sampled from soybean fields near the trials in Mato Grosso State, was grown in a PDA medium in Petri dishes. After 10 days of growing at $25^{\circ} \mathrm{C}$ and $12 \mathrm{~h}$ day length, $20 \mathrm{~mL} \mathrm{SDW}$ was added to each plate, and suspensions $\left(5 \times 10^{3}\right.$ to $1 \times 10^{4}$ conidia $\left.\mathrm{mL}^{-1}\right)$ were prepared to inoculate soybean plants in the field. Inoculations were carried out in soybean vegetative stages V6-V8 (5-7 trifoliate leaves, 6-8 nodes) (10) by spraying conidial suspension over the whole plant.

The fungicides boscalid ( $75 \mathrm{~g}$ a.i. $\left.\mathrm{ha}^{-1}\right)$, carbendazim (500 g a.i. $\left.\mathrm{ha}^{-1}\right)$, cyproconazole (30 g a.i. ha $\left.{ }^{-1}\right)$, fluxapyroxad $\left(50 \mathrm{~g}\right.$ a.i. ha $\left.{ }^{-1}\right)$ and prothioconazole ( $70 \mathrm{~g}$ a.i. $\left.\mathrm{ha}^{-1}\right)$, as well as an unsprayed control, were evaluated. Fungicides were sprayed three times. In the 2011/2012 season, inoculations were performed on December 30, 2011, and fungicides were sprayed on plants in the V8, R2, and R5.1 stages. In the 2012/2013 season, inoculations were performed on January 4, 2013, and fungicide treatments were sprayed on plants in R1, R4, and R5.3 stages. In the 2013/2104 crop season, inoculations were performed on January 17, 2014, in Querência, and on January 16, 2014, in Nova 
Xavantina. Fungicide treatments were sprayed on plants in R1, R4, and R5.2 stages in Querência, and in R1, R4, and R5.2 stages in Nova Xavantina.

Fungicides were sprayed by using a $\mathrm{CO}_{2}$-powered backpack sprayer, at $300 \mathrm{kPa}$ and approximately $150 \mathrm{~L} \mathrm{ha}^{-1}$, with a flat fantype nozzle (AVI 11002). Target spot severity was assessed in the two central rows of each plot. Disease severity was assessed three times (seven days before the first fungicide application, seven days after the second fungicide application, and seven days after the third fungicide application) with a diagrammatic scale (29). Disease progress curves were plotted, and each area under the disease progress curve (AUDPC) was determined (13). The two central lines of each plot were manually harvested, and the grain yield was calculated. Yield values were estimated for one hectare $\left(\mathrm{kg} \mathrm{ha}^{-1}\right)$. To estimate the fungicide efficacy on disease control and the yield reduction, the overall mean for AUDPC and soybean grain yield of all field assays were calculated and compared with those for the untreated control.

\section{Statistical analysis}

For in vitro tests, F statistic was used to check the goodness of fit $(P<0.05)$. Each experiment (for each fungicide) was conducted

Table 3. Identification code, year of isolation and Brazilian state of origin of the Corynespora cassiicola isolates, and effective concentrations of the fungicides carbendazim, thiophanate-methyl, cyproconazole and prothioconazole to reduce $50 \%$ mycelial growth - $\mathrm{EC}_{50}\left(\mu \mathrm{g} \mathrm{mL}^{-1}\right)$ and sensitivity level to MBC and DMI fungicides.

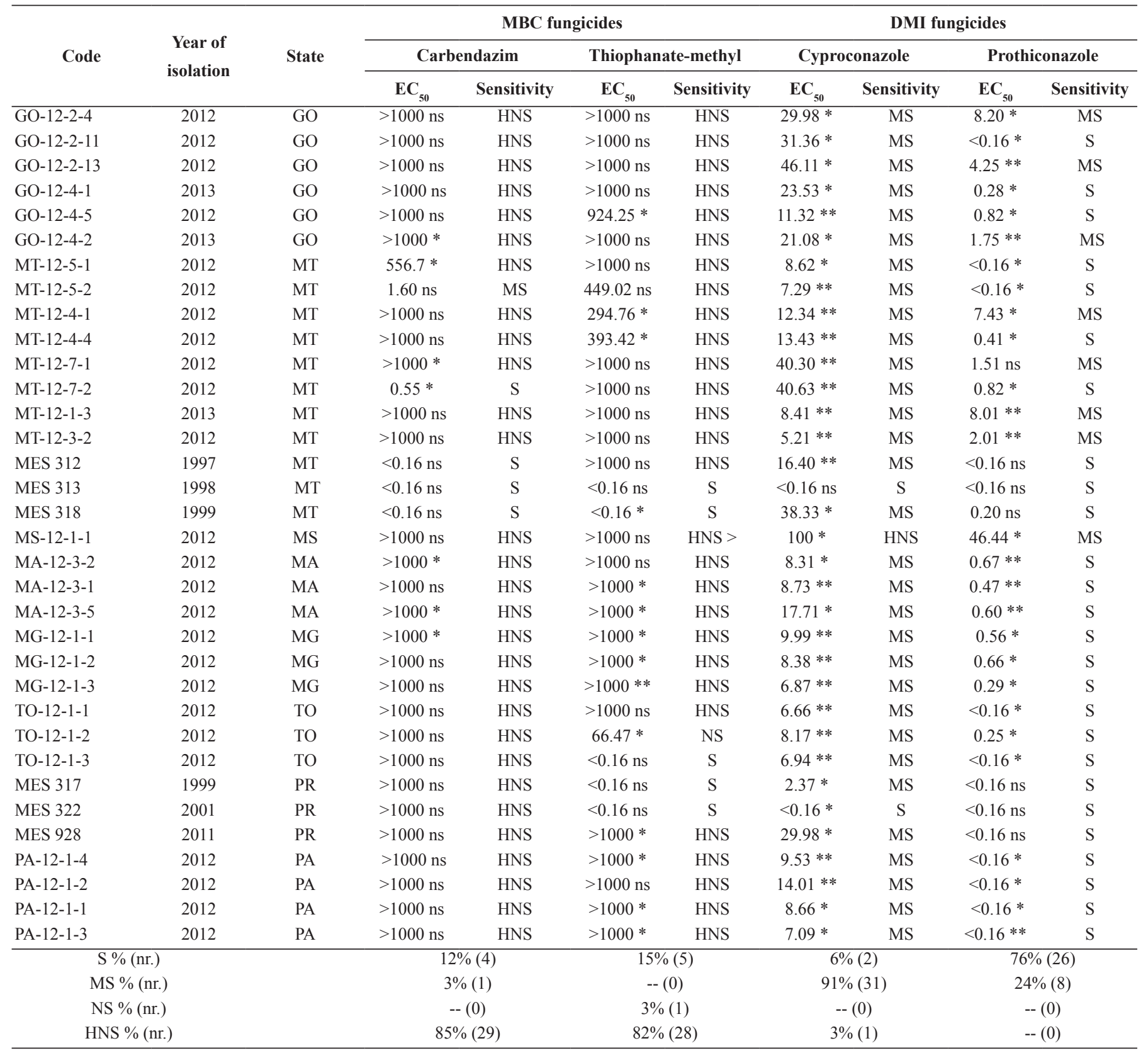

$\mathrm{S}=$ sensitive to fungicide $\left(\mathrm{EC}_{50}<1 \mu \mathrm{g} \mathrm{mL}^{-1}\right) ; \mathrm{MS}=$ moderately sensitive to fungicide $\left(\mathrm{EC}_{50} 1-50 \mu \mathrm{g} \mathrm{mL}^{-1}\right) ; \mathrm{NS}=$ non-sensitive to fungicide $\left(\mathrm{EC}_{50} 50-100 \mu \mathrm{g} \mathrm{mL}^{1}\right) ; \mathrm{HNS}=$ highly non-sensitive to fungicide $\left(\mathrm{EC}_{50}>100 \mu \mathrm{g} \mathrm{mL} \mathrm{m}^{-1}\right)$ [adapted from Avozani et al. (4) ${ }^{*}=$ Statistical significance at $5 \%$ probability; $* * \stackrel{=}{=}$ statistical significance at $1 \%$ probability; $\mathrm{ns}=$ not statistically significant. 
five times. Data were pooled only when the hypothesis of equal variances was not rejected. All statistical analyses were performed using the SAS version 9.0 routine (SAS Institute, Cary, NC).

Data were pooled from three field trials for grain yield (hypothesis of equal variances was not rejected) and from all trials for AUDPC. Variables were subjected to ANOVA and the means were subjected to multiple comparisons. Pearson correlation was performed between yield and AUDPC. All statistical analyses were performed by using SAS version 9.0 routine (SAS Institute, Cary, NC).

\section{RESULTS AND DISCUSSION}

In vitro mycelial growth inhibition of $C$. cassiicola

Most of the $C$. cassiicola isolates tested with MBC fungicides showed sensitivity reduction $\left(\mathrm{EC}_{50}\right.$ values were greater than 100 $\mu \mathrm{g} \mathrm{mL}^{1}$ ); non-sensitivity was $85 \%$ for carbendazim and $82 \%$ for thiophanate-methyl (Table 3). None of the tested isolates were nonsensitive to the SDHI fungicide fluopyram. In addition, $3 \%$ isolates were non-sensitive and highly non-sensitive to boscalid, another SDHI fungicide. On the other hand, fluxapyroxad had the highest

Table 4. Identification code, year of isolation and Brazilian state of origin of the Corynespora cassiicola isolates, and effective concentrations of the fungicides fluxapyroxad, boscalid and fluopyram to reduce $50 \%$ mycelial growth - $\mathrm{EC}_{50}\left(\mu \mathrm{g} \mathrm{mL} \mathrm{m}^{-1}\right)$ and sensitivity level to $\mathrm{SDHI}$ fungicides.

\begin{tabular}{|c|c|c|c|c|c|c|c|c|}
\hline \multirow[b]{2}{*}{ Code } & \multirow{2}{*}{$\begin{array}{c}\text { Year of } \\
\text { isolation }\end{array}$} & \multirow[b]{2}{*}{ State } & \multicolumn{6}{|c|}{ SDHI fungicides } \\
\hline & & & \multicolumn{2}{|c|}{ Fluxapyroxad } & \multicolumn{2}{|c|}{ Boscalid } & \multicolumn{2}{|c|}{ Fluopyram } \\
\hline GO-12-2-4 & 2012 & GO & $0.17 *$ & $\mathrm{~S}$ & $2.95 * *$ & MS & $2.27 * *$ & MS \\
\hline GO-12-2-13 & 2012 & GO & $0.19^{*}$ & S & $3.43 * *$ & MS & $2.10 * *$ & MS \\
\hline GO-12-4-1 & 2013 & GO & $<0.16^{*}$ & S & $12.22 *$ & NS & $5.87 *$ & MS \\
\hline GO-12-4-5 & 2012 & GO & $<0.16 * *$ & S & $2.10 *$ & MS & $0.86 *$ & $\mathrm{~S}$ \\
\hline MT-12-5-1 & 2012 & MT & $<0.16 *$ & S & $0.86 *$ & $\mathrm{~S}$ & $0.18 * *$ & S \\
\hline MT-12-5-2 & 2012 & MT & $<0.16^{* *}$ & S & $1.38 *$ & MS & $0.33 *$ & $\mathrm{~S}$ \\
\hline MT-12-4-1 & 2012 & MT & $<0.16^{*}$ & S & $2.62 *$ & MS & $1.53 * *$ & MS \\
\hline MT-12-4-4 & 2012 & MT & $<0.16 *$ & S & $4.85 *$ & MS & $1.67 * *$ & MS \\
\hline MT-12-7-1 & 2012 & MT & $<0.16 *$ & S & $7.53 * *$ & MS & $5.48 * *$ & MS \\
\hline MES 313 & 1998 & MT & $<0.16 \mathrm{~ns}$ & $\mathrm{~S}$ & $0.61 *$ & $\mathrm{~S}$ & $0.51 *$ & $\mathrm{~S}$ \\
\hline MES 318 & 1999 & MT & $<0.16^{*}$ & S & $0.80 *$ & $\mathrm{~S}$ & $0.23 *$ & $\mathrm{~S}$ \\
\hline MS-12-1-1 & 2012 & MS & $<0.16^{*}$ & S & $8.00 *$ & MS & $7.18^{*}$ & MS \\
\hline MA-12-3-2 & 2012 & MA & $<0.16^{*}$ & S & $1.49 *$ & MS & $0.64 * *$ & $\mathrm{~S}$ \\
\hline MA-12-3-1 & 2012 & MA & $<0.16^{*}$ & S & $2.57 *$ & MS & $1.55 * *$ & MS \\
\hline MA-12-3-5 & 2012 & MA & $<0.16^{*}$ & S & $1.77 *$ & MS & $0.22 *$ & $\mathrm{~S}$ \\
\hline MG-12-1-1 & 2012 & MG & $<0.16^{*}$ & S & $0.69 \mathrm{~ns}$ & $\mathrm{~S}$ & $0.69^{*}$ & S \\
\hline MG-12-1-2 & 2012 & MG & $<0.16 *$ & S & $2.67 *$ & MS & $0.55 *$ & $\mathrm{~S}$ \\
\hline MG-12-1-3 & 2012 & MG & $<0.16 *$ & $\mathrm{~S}$ & $1.25 *$ & MS & $0.75 *$ & $\mathrm{~S}$ \\
\hline TO-12-1-1 & 2012 & TO & $1.42 * *$ & MS & $0.99 *$ & $\mathrm{~S}$ & $2.68 * *$ & MS \\
\hline PA-12-1-1 & 2012 & $\mathrm{PA}$ & $0.32 *$ & S & $6.22 * *$ & MS & $0.51 *$ & $\mathrm{~S}$ \\
\hline PA-12-1-3 & 2012 & PA & $<0.16 \mathrm{~ns}$ & S & $3.94 * *$ & MS & $0.71 *$ & S \\
\hline \multicolumn{2}{|c|}{ S \% (nr.) } & & \multicolumn{2}{|c|}{$85 \%(29)$} & \multicolumn{2}{|c|}{$21 \%(7)$} & \multicolumn{2}{|c|}{$50 \%(17)$} \\
\hline \multicolumn{2}{|c|}{ MS \% (nr.) } & & \multicolumn{2}{|c|}{$6 \%(2)$} & \multicolumn{2}{|c|}{$73 \%(25)$} & \multicolumn{2}{|c|}{$50 \%(17)$} \\
\hline \multicolumn{2}{|c|}{ NS \% (nr.) } & & \multicolumn{2}{|c|}{$--(0)$} & \multicolumn{2}{|c|}{$3 \%(1)$} & \multicolumn{2}{|c|}{$--(0)$} \\
\hline \multicolumn{2}{|c|}{ HNS \% (nr.) } & & \multicolumn{2}{|c|}{$9 \%(3)$} & \multicolumn{2}{|c|}{$3 \%(1)$} & \multicolumn{2}{|c|}{$--(0)$} \\
\hline
\end{tabular}

$\mathrm{S}=$ sensitive to fungicide $\left(\mathrm{EC}_{50}<1 \mu \mathrm{g} \mathrm{mL}^{-1}\right) ; \mathrm{MS}=$ moderately sensitive to fungicide $\left(\mathrm{EC}_{50} 1-10 \mu \mathrm{g} \mathrm{mL}^{-1}\right) ; \mathrm{NS}=$ non-sensitive to fungicide $\left(\mathrm{EC}_{50} 10-25 \mu \mathrm{g} \mathrm{mL}^{-1}\right)$; $\mathrm{HNS}=$ highly non-sensitive to fungicide $\left(\mathrm{EC}_{50}>25 \mu \mathrm{g} \mathrm{mL}^{-1}\right)$ [adapted from Miyamoto et al. (23)]. * = Statistical significance at $5 \%$ probability; $* *=$ statistical significance at $1 \%$ probability; ns $=$ not statistically significant. 
Table 5. Percentage of in vitro spore germination (SG) of four Corynespora cassiicola isolates to fungicides with or without salicylhydroxamic acid (SHAM).

\begin{tabular}{|c|c|c|c|c|c|c|c|c|c|c|c|c|}
\hline \multirow{3}{*}{ Treatment } & \multicolumn{12}{|c|}{ Isolates } \\
\hline & \multicolumn{3}{|c|}{ MES 322} & \multicolumn{3}{|c|}{ MG-05 } & \multicolumn{3}{|c|}{ Sinop 1} & \multicolumn{3}{|c|}{ MES 313} \\
\hline & SG* & $\chi^{2}$ & $P$ & SG & $\chi^{2}$ & $P$ & SG & $\chi^{2}$ & $P$ & SG & $\chi^{2}$ & $\mathbf{P}$ \\
\hline Azoxystrobin & 2.0 & 0.11 & 0.737 & 89.2 & 0.02 & 0.886 & 88.4 & 0.02 & 0.888 & 4.8 & 0.35 & 0.553 \\
\hline Azoxystrobin + SHAM & 1.6 & & & 88.8 & & & 88.8 & & & 6.0 & & \\
\hline Pyraclostrobin & 0.4 & 1.01 & 0.315 & 83.6 & 0.01 & 0.903 & 23.2 & 0.18 & 0.668 & 0.8 & 15.41 & 0.000 \\
\hline Pyraclostrobin + SHAM & 1.2 & & & 84.0 & & & 21.6 & & & 8.0 & & \\
\hline Picoxystrobin & 1.2 & 1.02 & 0.313 & 88.4 & 12.87 & 0.000 & 88.0 & 1.77 & 0.184 & 9.6 & 0.00 & 1.000 \\
\hline Picoxystrobin + SHAM & 2.4 & & & 96.8 & & & 91.6 & & & 9.6 & & \\
\hline Trifloxystrobin & 2.0 & 2.98 & 0.084 & 95.6 & 0.38 & 0.538 & 92.0 & 0.23 & 0.632 & 7.2 & 0.03 & 0.864 \\
\hline Trifloxystrobin + SHAM & 4.8 & & & 94.4 & & & 90.8 & & & 7.6 & & \\
\hline
\end{tabular}

Table 6. Identification code, year of isolation and Brazilian state of origin of the Corynespora cassiicola isolates, and effective concentrations of the fungicides pycoxystrobin, pyraclostrobin, azoxystrobin and trifloxystrobin to reduce $50 \%$ spore germination $-\mathrm{EC}_{50}\left(\mu \mathrm{g} \mathrm{mL} \mathrm{L}^{-1}\right)$ and sensitivity level to QoI fungicides.

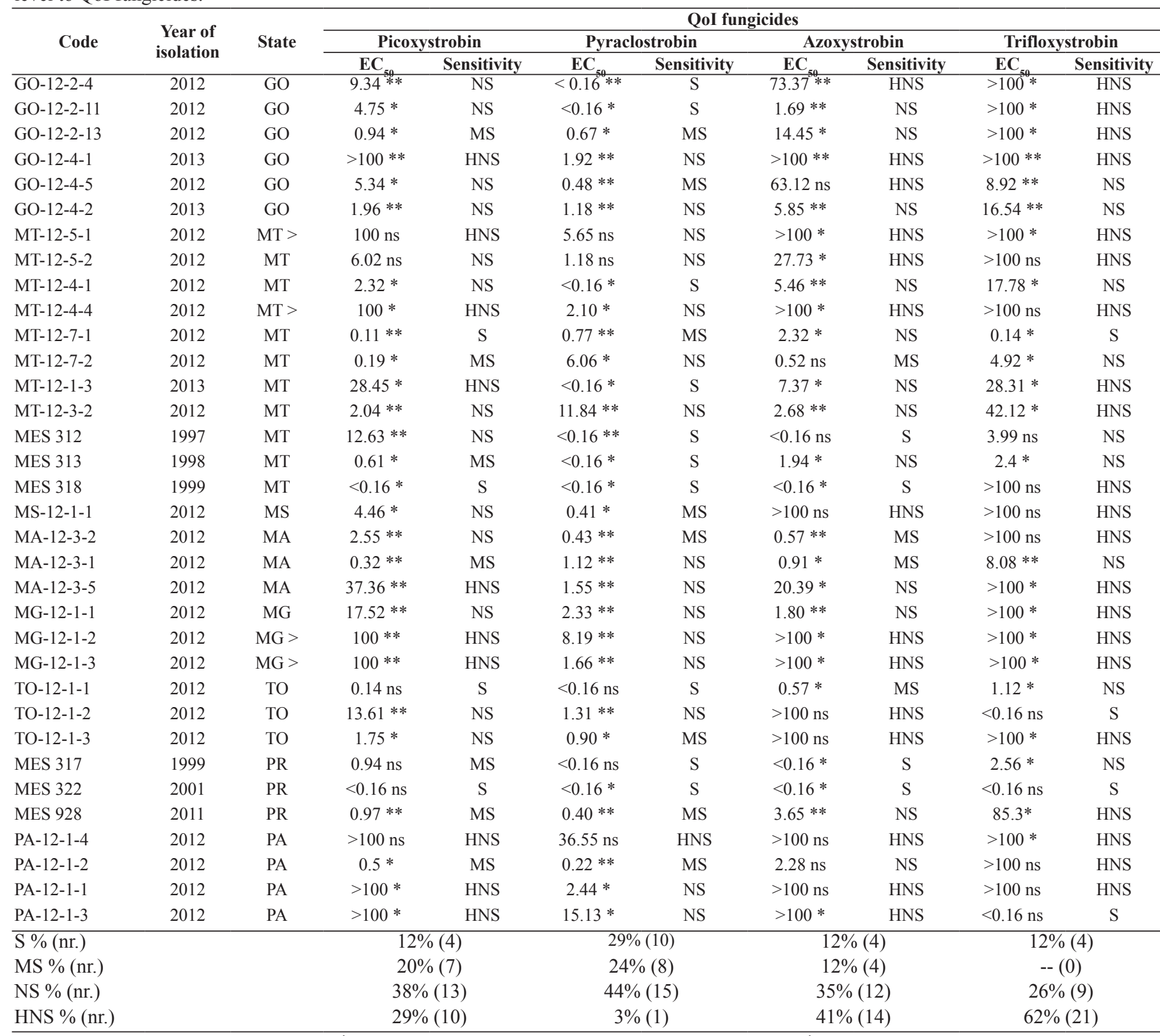

$\mathrm{S}=$ sensitive to fungicide $\left(\mathrm{EC}_{50}<0.16 \mu \mathrm{g} \mathrm{mL}{ }^{-1}\right) ; \mathrm{MS}=$ moderately sensitive to fungicide $\left(\mathrm{EC}_{50} 0.16-1 \mu \mathrm{g} \mathrm{mL} \mathrm{mL}^{-1}\right)$; $\mathrm{NS}=$ non-sensitive to fungicide $\left(\mathrm{EC} \mathrm{f}_{50} 1-25 \mu \mathrm{g}\right.$ $\left.\mathrm{mL}^{-1}\right) ; \mathrm{HNS}=$ highly non-sensitive to fungicide $\left(\mathrm{EC}_{50}>25 \mu \mathrm{gL}^{-1}\right)$ [adapted from Leroux et al. $(20)$ ]. * = Statistical significance at $5 \%$ probability; $* *=$ statistical significance at $1 \%$ probability; ns $=$ not statistically significant. 
frequency of sensitive isolates ( $85 \%$ ) but also shows three isolates as highly non-sensitive (Table 4). The DMI fungicides prothioconazole and cyproconazole had 0 and 3\% non-sensitive isolates, respectively (Table 3).

\section{In vitro inhibition of $\boldsymbol{C}$. cassiicola spore germination}

The interaction SHAM $\times$ isolate was not significant $(\mathrm{P}=0.7113)$. ANOVA indicated that SHAM had no effect on the sensitivity of $C$. cassiicola conidial germination $(\mathrm{P}=0.9462)$. Only the factor isolate had significant effects in the analysis $(\mathrm{P}=0.0001)$.

For the in vitro percentage of spore germination, with or without SHAM, there was no difference between the expected and the null hypothesis, based on Chi-square tests for all combinations QoI fungicide $x$ SHAM (Table 5), except for isolate MES 313, for which addition of SHAM to the fungicide pyraclostrobin enhanced spore germination $\left(c^{2}=15.4 ; \mathrm{P}=0.0009\right)$.

Pyraclostrobin had higher percentage of sensitive and moderately sensitive isolates of $C$. cassiicola (53\%) than the other fungicides. Most of the isolates were non-sensitive to picoxystrobin (68\%), azoxystrobin $(76 \%)$, and trifloxystrobin (88\%) (Table 6).

\section{Effect of fungicides on target spot progress under field} conditions

There was a significant interaction among fungicide treatment and field trials for AUDPC $(\mathrm{P}=0.0001)$ and for soybean yield $(\mathrm{P}=0.0002)$ (Table 7). This significance led us to carry out one-way ANOVAs for each field trial (Table 8).

In the trial conducted in Nova Xavantina, in 2011/2012 crop season, a significant effect of the treatments was detected for AUDPC (P =
$0.001)$ but not for grain yield $(\mathrm{P}=0.796)$. All fungicide treatments had significantly lower AUDPC means than the untreated control. The most effective treatments in preventing the progress of target spot were the fungicides fluxapyroxad and prothioconazole, showing $78 \%$ and $87 \%$ control, respectively (Table 8 ).

In the 2012/2013 trial, there were significant effects on both AUDPC and yield ( $\mathrm{P}=0.001$ and 0.002 , respectively). A lower AUPDC was achieved by spraying prothioconazole, which had $79 \%$ control. However, soybean grain yield did not differ among fungicide treatments (Table 8).

Trials conducted in the 2013/2014 crop season in Nova Xavantina and Querência Municipalities had an extended period without rain in January. These drier days were unfavorable for the development of target spot epidemics. Although AUDPC means were lower, differences could be detected among fungicide treatments. In both locations, a lower AUDPC was achieved with fluxapyroxad treatment, but low percentages of control ( $26 \%$ to $43 \%$ ) were obtained (Table 8 ).

There was a negative and significant correlation between AUDPC and yield $(-0.265, \mathrm{P}=0.010)$. The overall mean for AUDPC with the untreated control was 520, while the lowest AUDPC mean was 143 (prothioconazole), a reduction of $72 \%$. Soybean treated with prothioconazole also had a higher grain yield $\left(2152 \mathrm{~kg} \mathrm{ha}^{-1}\right), 31 \%$ greater than that with the untreated control.

The means of target spot control in the four field trials varied from $26 \%$ to $55 \%$ and the mean of soybean yield reduction was $28 \%$ for the untreated control (Table 8).

There was no incidence of Asian soybean rust (P. pachyrhizi), and the incidence of other foliar diseases was not significant in all crop seasons.

Table 7. Combined analyses of variance of Area Under Disease Progress Curve (AUDPC) of soybean target spot and soybean grain yield (GY = $\mathrm{kg} \mathrm{ha}^{-1}$ ) of six fungicide treatments tested in 4 field trials (environments)

\begin{tabular}{|c|c|c|c|c|c|}
\hline \multirow{2}{*}{ Sources of variation } & \multirow{2}{*}{ df } & \multicolumn{2}{|c|}{$\mathbf{F}$} & \multicolumn{2}{|c|}{$P>\mathbf{F}$} \\
\hline & & AUDPC & GY & AUDPC & GY \\
\hline Environment & 3 & 314.12 & 51.61 & 0.0001 & 0.0001 \\
\hline Fungicide & 5 & 115.79 & 5.69 & 0.0001 & 0.0003 \\
\hline Environment $\mathrm{x}$ Fungicide & 15 & 43.22 & 3.72 & 0.0001 & 0.0002 \\
\hline Error & 60 & & & & \\
\hline Total & 95 & & & & \\
\hline
\end{tabular}

Table 8. Area Under Disease Progress Curve (AUDPC), soybean yield and control percentage of target spot in four field trials with soybeans artificially inoculated with Corynespora cassiicola in Nova Xavantina (NX) and Querência (QR), Mato Grosso State, Brazil. Crop seasons were 2011/2012 (11-12), 2012/2013 (12-13) and 2013/2014 (13-14).

\begin{tabular}{|c|c|c|c|c|c|c|c|c|c|c|c|c|c|c|c|c|c|}
\hline \multirow[b]{2}{*}{ Fungicide } & \multicolumn{3}{|c|}{ NX 11-12 } & \multicolumn{4}{|c|}{ NX 12-13 } & \multicolumn{4}{|c|}{ NX 13-14 } & \multicolumn{4}{|c|}{ QR 13-14 } & \multicolumn{2}{|c|}{ Mean } \\
\hline & AUDPC & $\begin{array}{c}\text { Disease } \\
\text { Control } \\
(\%) \\
\end{array}$ & $\begin{array}{c}\text { Yield } \\
\text { (kg/ha) }\end{array}$ & AUDPC & $\begin{array}{c}\text { Disease } \\
\text { Control } \\
(\%) \\
\end{array}$ & $\begin{array}{c}\text { Yield } \\
\text { (kg/ha) }\end{array}$ & $\begin{array}{c}\text { Yield } \\
\text { Reduction } \\
(\%) \\
\end{array}$ & AUDPC & $\begin{array}{c}\text { Disease } \\
\text { Control } \\
(\%) \\
\end{array}$ & $\begin{array}{c}\text { Yield } \\
(\mathrm{kg} / \mathrm{ha})\end{array}$ & $\begin{array}{c}\text { Yield } \\
\text { Reduction } \\
(\%) \\
\end{array}$ & AUDPC & $\begin{array}{c}\text { Disease } \\
\text { Control } \\
(\%) \\
\end{array}$ & $\begin{array}{c}\text { Yield } \\
\text { (kg/ha) }\end{array}$ & $\begin{array}{c}\text { Yield } \\
\text { Reduction } \\
(\%) \\
\end{array}$ & $\begin{array}{c}\text { Disease } \\
\text { Control } \\
(\%) \\
\end{array}$ & $\begin{array}{c}\text { Yield } \\
\text { Reduction } \\
(\%) \\
\end{array}$ \\
\hline Untreated & $984 \mathrm{a}$ & 0 & $2009 \mathrm{~ns}$ & $661 \mathrm{a}$ & 0 & $1274 \mathrm{~b}$ & 39 & $265 \mathrm{a}$ & 0 & $1486 \mathrm{~b}$ & 31 & $170 \mathrm{a}$ & 0 & $2152 \mathrm{a}$ & 14 & 0 & 28 \\
\hline Boscalid & $495 \mathrm{~b}$ & 50 & 2176 & $368 \mathrm{c}$ & 44 & 2084 a & 0 & $174 \mathrm{bc}$ & 34 & $1518 \mathrm{~b}$ & 29 & $134 \mathrm{ab}$ & 21 & $2388 \mathrm{ab}$ & 4 & 37 & 11 \\
\hline Carbendazim & $483 \mathrm{~b}$ & 51 & 1745 & $543 \mathrm{ab}$ & 18 & 1779 a & 15 & $171 \mathrm{bc}$ & 35 & $1609 \mathrm{~b}$ & 25 & $148 \mathrm{ab}$ & 13 & $2478 \mathrm{~b}$ & 1 & 29 & 14 \\
\hline Cyproconazole & $343 \mathrm{c}$ & 65 & 2029 & $682 \mathrm{a}$ & 0 & 1882 a & 10 & $200 \mathrm{~b}$ & 25 & $1525 \mathrm{~b}$ & 29 & $149 \mathrm{ab}$ & 12 & $2402 \mathrm{ab}$ & 4 & 26 & 14 \\
\hline Fluxapyroxad & $213 d$ & 78 & 1965 & $452 \mathrm{bc}$ & 32 & $1749 \mathrm{ab}$ & 16 & $150 \mathrm{c}$ & 43 & 2071 a & 4 & $126 \mathrm{~b}$ & 26 & $2474 \mathrm{~b}$ & 1 & 45 & 7 \\
\hline Prothioconazole & $127 \mathrm{~d}$ & 87 & 1847 & $141 \mathrm{~d}$ & 79 & $1740 \mathrm{ab}$ & 17 & $158 \mathrm{bc}$ & 40 & $2153 \mathrm{a}$ & 0 & $147 \mathrm{ab}$ & 14 & $2494 \mathrm{~b}$ & 0 & 55 & 6 \\
\hline Mean & 441 & & 1960 & 474 & & 1751 & & 186 & & 1727 & & 146 & & 2398 & & & \\
\hline C.V. $(\%)$ & 12.2 & & 18.4 & 15.3 & & 11.95 & & 10.14 & & 6.04 & & 11.55 & & 4.61 & & & \\
\hline $\mathbf{P}$ & 0.001 & & 0.796 & 0.001 & & 0.002 & & 0.001 & & 0.001 & & 0.034 & & 0.005 & & & \\
\hline
\end{tabular}

Means followed by the same letter in each column do not differ according to Tukey's test at $5 \%$ probability. ns= not statistically significant. 
Due to the intensification of fungicide usage (two to four sprays per season) in Brazilian soybean production areas over the last 13 years in order to control Asian soybean rust and other foliar diseases, the selection pressure on soybean pathogen complexes has been high and may have caused resistant isolates to arise (14).

The MBC fungicides carbendazim and thiophanate-methyl have been used in the last decade to control target spot, anthracnose (Colletotrichum truncatum (Schw.) Andrus \& Moore, 1935), Cercospora leaf blight (Cercospora kikuchii T. Matumoto \& Tomoy, 1925), and Septoria brown spot (Septoria glycines Hemmi, 1915), but their efficacy has been decreasing year after year. In this study, $90 \%$ and $85 \%$, respectively, of the sampled $C$. cassiicola isolates showed reduction in the sensitivity to these fungicides, according to the classification proposed by Edgington et al. (8). Most isolates had $\mathrm{EC}_{50}$ values above the highest tested concentration $\left(1000 \mu \mathrm{g} \mathrm{mL}^{-1}\right)$, indicating resistance of $C$. cassiicola to carbendazim and thiophanate-methyl in Brazil. Similar results were obtained in other studies $(26,31,33)$.

In a recent survey, there was evidence of sensitivity of $C$. cassiicola to carbendazim only in samples collected before 2007, and nonsensitivity in recent isolates obtained after 2008 (33). These authors considered isolates sensitive when $\mathrm{EC}_{50} \leq 1.0 \mu \mathrm{g} \mathrm{mL}^{-1}$, and highly resistant when $\mathrm{EC}_{50} \geq 50 \mu \mathrm{g} \mathrm{mL}^{-1}$.

The fungicide cyproconazole had the highest mean of $\mathrm{EC}_{50}$ in the test for mycelial growth inhibition. Most isolates (94\%) were non-sensitive $\left(\mathrm{EC}_{50}>1.0 \mu \mathrm{g} \mathrm{mL}^{-1}\right)$ to cyproconazole. Even though non-sensitivity occurred, the mean $\mathrm{EC}_{50}$ was higher for isolates from southern Brazil.

DMI fungicides were the first to be widely used after the initial Asian soybean rust epidemics in Brazil, followed by QoI solo or in mix formulations with DMI. Low sensitivity may be a result of the extensive use of cyproconazole in Brazil. This fungicide is the most common DMI found in the commercial mix formulations of DMI and QoI, widely sprayed in soybean fields. The difference in $\mathrm{EC}_{50}$ can be attributed to longer exposure to the fungicide by isolates from the southern population. In another survey carried out in 2011, five $C$. cassiicola isolates taken from soybean were considered moderately resistant to cyproconazole (4).

As for prothioconazole, another DMI fungicide, the percentage of non-sensitive isolates was $23 \%$. This result demonstrates the existence of non-sensitive isolates, mainly collected in the northern part of Brazil, as $\mathrm{EC}_{50}$ values above $67 \mu \mathrm{g} \mathrm{mL}^{-1}$ were estimated. Variability in sensitivity to prothioconazole was also found by Xavier et al. (33), who tested 24 isolates of $C$. cassiicola with prothioconazole and obtained an $\mathrm{EC}_{50}$ ranging from $0.47 \mu \mathrm{g} \mathrm{mL}^{-1}$ to $26.44 \mu \mathrm{g} \mathrm{mL}^{-1}$.

Sensitivity of $C$. cassiicola isolates to the SDHI fungicides fluopyram, fluxapyroxad and boscalid was not equal. Most isolates were sensitive to fluxapyroxad, while others were non-sensitive to fluopyram and boscalid. $\mathrm{EC}_{50}$ means for fluopyram and boscalid were lower than $5 \mu \mathrm{g} \mathrm{mL}^{-1}$; however, there were isolates with an $\mathrm{EC}_{50}$ higher than $5 \mu \mathrm{g} \mathrm{mL}^{-1}$. From the SDHI fungicides, boscalid had the highest $\mathrm{EC}_{50}$. There are other reports of fungicide resistance to boscalid for $C$. cassiicola $(23,24)$.

This variability in sensitivity to SDHI fungicides by Brazilian $C$. cassiicola isolates represents a serious concern for long-term fungicide management and for preventing the emergence of resistance. Therefore, fungicides of this group must be used with extreme care in order to minimize directional selection on the pathogen and to avoid the premature inefficacy of fungicides to control target spot in soybean plants.

Conidial germination is directly affected by QoI fungicides (25). Assessment of spore germination is a suitable method to evaluate the sensitivity to this fungicide group. Isolates of C. cassiicola in this study ranged from sensitive to highly non-sensitive to all evaluated QoI fungicides. Most of the isolates were sensitive (29\%) or moderately sensitive (24\%) to pyraclostrobin, and only $3 \%$ isolates were highly non-sensitive. For the other QoIs, the frequency of highly non-sensitive isolates was much higher, reaching $62 \%$ to trifloxystrobin, $41 \%$ to azoxystrobin and $29 \%$ to picoxystrobin.

Higher spore germination $\mathrm{EC}_{50}$ values were also found for five C. cassiicola isolates from soybean to azoxystrobin $\left(6.20 \mu \mathrm{g} \mathrm{mL}^{-1}\right)$, picoxystrobin $\left(2.74 \mu \mathrm{g} \mathrm{mL}^{-1}\right)$, and pyraclostrobin $\left(1.47 \mu \mathrm{g} \mathrm{mL}^{-1}\right)(4)$.

There are reports of resistance of $C$. cassiicola to QoI fungicides $(7,17)$. The variation in sensitivity reduction factor (from 100.6-fold to 8984.5 -fold) found in this study indicates occurrence of resistance in $C$. cassiicola from soybean in Brazil. Crossing resistance appears to occur in some isolates. Seven isolates (GO 12-4-1, MT 12-5-1, MT 12-4-4, MG 12-1-2, MG 12-1-2, PA 12-1-4 and PA 12-1-1) were highly resistant to all QoI fungicides, except pyraclostrobin. This may suggest a diverse resistance mechanism for that compound.

Studies with plant pathogenic fungi, in which strobilurin resistance was examined at molecular level, revealed that resistance often correlates with a point mutation in target cytochrome $b$ gene when replacing glycine with alanine at amino acid codon 143 makes an individual resistant to strobilurin (27). Nevertheless, in some cases, other mutations are still present (3). On the other hand, isolate MES 318 was sensitive to all tested QoI fungicides but not to trifloxystrobin. Only one isolate (MES 322) was sensitive to all fungicides.

Considering the in vitro assays, the site of action of QoI fungicides can in principle be bypassed by an alternative oxidase, which is inhibited by salicylhydroxamic acid (SHAM) or propyl gallate (22). In this study, there was no effect of SHAM in increasing the sensitivity of four $C$. cassiicola isolates to QoI fungicides, which made us disregard the use of SHAM for all evaluated isolates.

In four field experiments, carbendazim was not effective in controlling target spot in soybean. These results reinforce the in vitro tests. On the other hand, prothioconazole consistently prevented target spot epidemics in all field assays. However, this fungicide must be used with caution, especially in northern regions, where the frequency of non-sensitive isolates is higher. Among SDHI fungicides, fluxapyroxad had better results in the field, corroborating the in vitro results. In general, the efficacy of fungicides in the field reflected the in vitro sensitivity measures.

In the field trials of this study, the averages of target spot control and of soybean yield reduction had the same trend as the ones observed in the Brazilian network trials for soybean target spot (15), although the fungicides used in those network trials are formulated in mixtures of at least two different modes of action.

Prothioconazole and fluxapyroxad provided the highest in vitro inhibition of mycelial growth, and pyraclostrobin had the highest inhibition of in vitro spore germination, with the lowest $\mathrm{EC}_{50}$ values. Widespread non-sensitivity to $\mathrm{MBC}$ was detected, indicating that this group of fungicides should no longer be used for target spot control. The pathogen showed variability in sensitivity to SDHI, DMI and QoI fungicides, which denoted a high risk to selection for resistance and suggests that multiple resistance to fungicides can occur in C. cassiicola. 


\section{REFERENCES}

1. Almeida, A.M.R.; Ferreira, L.P.; Yorinori, J.T.; Silva, J.F.V.; Henning, A.A.; Godoy, C.V.; Costamilan, L.M; Meyer, M.C. Doenças da Soja. In: Kimati, H.; Amorim, L.; Rezende, J.A.M.; Bergamin Filho, A.; Camargo, L.E.A. (Ed.). Manual de fitopatologia: doenças das plantas cultivadas. 4.ed. São Paulo: Editora Agronômica Ceres, 2005. v.1, cap.64, p.569-588.

2. Almeida, A.M.R.; Machado, C.C.; Ferreira, L.P.; Lehman, P.S.; Antonio, H. Ocorrência de Corynespora cassiicola (Berk. \& Curt.) Wei no Estado de São Paulo. Fitopatologia Brasileira, Brasília, DF, v.1, n.2, p.111-112, 1976.

3. Avila-Adame, C.; Olaya, G.; Koller, W. Characterizarion of Colletotrichum graminicola isolates resistant to strobilurin related QoI fungicides. Plant Disease, St. Paul, v.87, n.12, p.1426-1432, 2003.

4. Avozani, A.; Reis, E.M.; Tonin, R.B. Sensitivity loss by Corynespora cassiicola, isolated from soybean, to the fungicide carbendazim. Summa Phytopathologica, Botucatu, v. 40, n. 2, p. 273-276, 2014.

5. Companhia Nacional de Abastecimento. Acompanhamento da safra brasileira de grãos - safra 2013/14. Brasília: Conab, v. 1, n.1, p. 75-79, 2014a.

6. Companhia Nacional de Abastecimento. Séries históricas de área plantada, produtividade e produção - soja. Available at: $<$ http://www.conab.gov. $\mathrm{br} /$ conteudos.php? $\mathrm{a}=1252 \& \mathrm{t}=\&$ Pagina_objemsconteudos $=3 \neq$ Aobjcmsconteudos $>$. Accessed on May 10, 2014b.

7. Date, H.; Kataoka, E.; Tanina, K.; Sasaki, S.; Inoue, K.; Nasu, H.; Kasuyamam, S. Sensitivity of Corynespora cassiicola, causal agent of Corynespora leaf spot of cucumber, to tiophanate-methyl, dietofencarb and axoxystrobin. Japanese Journal of Phytopathology, Tokyo, v.70, n.1, p.10-13, 2004.

8. Edgington, L.V.; Klew, K.L.; Barron, G.L. Fungitoxic spectrum of benzimidazole compounds. Phytopathology, St. Paul, v.61, n.1, p.42-44, 1971.

9. Farr, D.F.; Rossman, A.Y.; Palm, M.E.; Maccray, E.B. Fungal databases. Beltsville: Systematic Botany \& Mycology Laboratory, 2009. Available at: <http://nt.ars-rin.gov/fungaldatabases $>$. Accessed on: February 8, 2010.

10. Fehr, W.R.; Caviness, C.E. Stage of soybean development. Ames: Iowa State University, 1981. 12p. (Iowa Cooperative Extensive Service Special Report, 80).

11. Figueiredo, M.B. Estudos sobre a aplicação do método de Castellani para conservação de fungos patógenos em plantas. O Biológico, São Paulo, v.33, n.1, p.9-13, 1967.

12. FRAC. FRAC Code List $^{\circ}$ 2017: fungicides sorted by mode of action (including FRAC Code number). Basel, 2017. Available at: <http:// www.frac.info/docs/default-source/publications/frac-code-list/frac-codelist-2017-final.pdf?sfvrsn=fab94a9a 2>. Accessed on: June 13, 2017.

13. Fry, W.E. Integrated control of potato late blight: Effects of polygenic resistance and techniques of timing fungicide applications. Phytopathola ogy, St. Paul, v.67, n.3, p.415-420, 1977.

14. Godoy, C.V.; Meyer, M.C. Resistência a fungicidas na cultura da soja. Informativo Meridional, Londrina, v.14, n.51, p.5, 2014.

15. Godoy, C.V.; Utiamada, C.M.; Meyer, M.C.; Campos, H.D.; Pimenta, C.B.; Borges, E.P.; Siqueri, F.V.; Juliatti, F.C.; Nunes Junior, J.; Carneiro, L.C.; Silva, L.H.C.P.; Sato, L.N.; Canteri, M.G.; Madalosso, M.; Volf, M.R.; Martins, M.C.; Balardin, R.S.; Montecelli, T.D.N.; Carlin, V.J.; Venâncio, W.S. Eficiência de fungicidas para o controle da mancha-alvo, Corynespora cassiicola, na safra 2012/13: resultados sumarizados dos ensaios cooperativos. Londrina: Embrapa Soja, 2013. 6p. (Circular Técnica, 100).

16. Henning, A.A.; Almeida, A.M.R.; Godoy, C.V.; Seixas, C.D.S.; Yorinori,
J.T.; Costamilan, L.M.; Ferreira, L.P.; Meyer, M.C.; Soares, R.M.; Dias, W.P. Manual de identificação de doenças de soja. 4.ed. Londrina: Embrapa Soja, 2012. 74 p. (Documentos, 256).

17. Ishii, H. Resistance management strategies for fungicides. In: Clark, J.M.; Ohkawa, H. (Ed.). Environmental fate and safety management of agrochemicals. Washington, DC: American Chemical Society, 2005. p. $280-288$

18. Kleffmann Group. Crop Protection Products: Foliar Fungicides: AMIS Soybean 11/12. Ludinghausen, 2012.

19. Koenning, S.R.; Creswell, T.C.; Dunphy, E.J.; Sikora, E.J.; Mueller, J.D. Increased occurrence of target spot of soybean caused by Corynespora cassiicola in the Southeastern United States. Plant Disease, St. Paul, v.90, n.7, p.974, 2006.

20. Leroux, P.; Gredt, M.; Leroch, M.; Walker, A.S. Exploring mecanisms of resistance to respiratory inhibitors in field strains of Botrytis cinerea, the causal agent of gray mold. Applied Environmental Microbiology, Washington, v.76, n.19, p.6615-6630, 2010.

21. Meyer, M.C.; Godoy, C.V.; Venâncio, W.S.; Teramoto, A. Manejo equilibrado. Cultivar Grandes Culturas, Pelotas, v. 14, n. 165, p.3-7, 2013. Caderno Técnico.

22. Miguez, M.; Reeve, C.; Wood, P. M.; Hollomon, D. W. Alternative oxidase reduces the sensitivity of Mycosphaerella graminicola to QOI fungicides. Pest Management Science, Hoboken, v.60, n.1, p.3-7, 2004.

23. Miyamoto, T.; Ishii, H.; Seko, T.; Kobori, S.; Tomita, Y. Occurrence of $\mathrm{Co}$ rynespora cassiicola isolates resistant to boscalid on cucumber in Ibaraki Prefecture, Japan. Plant Pathology, London, v.58, p.1144-1151, 2009.

24. Miyamoto, T.; Ishii, H.; Stammler, G.; Koch, A.; Ogawara, T.; Tomita, Y.; Fountaine, J.M.; Ushio, S.; Kobori, S. Distribution and molecular characterization of Corynespora cassiicola isolates resistant to boscalid. Plant Pathology, London, v.59, p.873-881, 2010.

25. Olaya, G.; Zheng, D.; Koller, W. Differential responses of germinating Venturia inaequalis conidia to kresoxim-methyl. Pesticide Science, Tokyo, v.54, p.230-236, 1998.

26. Pereira, A.V.S. Sensibilidade a fungicidas e adaptabilidade de Lasiodiplodia theobromae patogênico ao mamão. 2009. 57 1. Dissertation (Master in Phytopathology) - UFRPE, Recife.

27. Sierotzki, H.; Wullschleger, J.; Gisi, U. Point-mutation in cytochrome b gene conferring resistance to strobilurin fungicides in Erysiphe graminis $\mathrm{f}$. sp. tritici field isolates. Pesticide Biochemistry Physiology, Amsterdan, v.68, p.107-112, 2000.

28. Sinclair, J.B. Target spot. In: Hartman, G.L.; Sinclair, J.B.; Rupe, J.C. (Ed.). Compendium of Soybean Diseases. St. Paul: The American Phytopathological Society, 1999. p.27.

29. Soares, R.M.; Godoy, C.V.; Oliveira, M.C.N. Escala diagramática para avaliação da severidade da mancha alvo da soja. Tropical Plant Pathology, Brasília, DF, v.34, n.5, p.333-338, 2009.

30. Embrapa. Tecnologias de produção de soja: região central do Brasil 2014. Londrina: Embrapa Soja, 2013. 265p. (Sistemas de Produção, 16)

31. Teramoto, A.; Martins, M.C.; Ferreira, L.C.; Cunha, M.G. Reaction of hybrids, inhibition in vitro and target spot control in cucumber. Horticultura Brasileira, Brasília, DF, v.29, n.3, p.342-348, 2011.

32. Teramoto, A.; Santos, L.M.; Machado, T.A.; Meyer, M.C.; Cunha, M.G. Sensitivity of Corynespora cassiicola isolates from Brazil to fungicides. In: International Congress of Plant Pathology. Abstracts... Beijing. Acta Phytopathologica Sinica, Beijing, v.43, p.140, 2013.

33. Xavier, S.A.; Canteri, M.G.; Barros, D.C.M.; Godoy, C.V. Sensitivity of Corynespora cassiicola from soybean to carbendazim and prothioconazole. Tropical Plant Pathology, Brasília, DF, v.38, n.5, p.431-435, 2013. 